\title{
Prognostic value of ABO blood group in southern Chinese patients with established nasopharyngeal carcinoma
}

\author{
P-Y OuYang ${ }^{1,3}, \mathrm{Z} \mathrm{Su}^{1,3}, \mathrm{Y}-\mathrm{P}$ Mao ${ }^{1}, \mathrm{Q} \mathrm{Liu}^{2}$ and F-Y Xie*,1
}

${ }^{1}$ Department of Radiation Oncology, Sun Yat-sen University Cancer Center, State Key Laboratory of Oncology in South China, Guangzhou, Guangdong 510060, China and ${ }^{2}$ Department of Epidemiology, Sun Yat-sen University Cancer Center, State Key Laboratory of Oncology in South China, Guangzhou, Guangdong 510060, China

Background: $A B O$ blood group is associated with aetiology of nasopharyngeal carcinoma (NPC); however, the effect of it on survival of patients diagnosed with NPC has not been explored.

Methods: We retrospectively analysed two cohorts of southern Chinese patients with WHO histological type III: intensitymodulated radiotherapy (IMRT) cohort, 924 patients; and conventional radiotherapy (CRT) cohort, 1193 patients. Associations of $\mathrm{ABO}$ blood group with survival were estimated using Cox regression.

Results: In IMRT cohort, we observed significant associations of blood type A with overall survival (OS) and distant metastasis-free survival (DMFS), compared with type $O$, after adjusting for prognostic factors. Compared with non- $A$ blood types (B, $A B$, and $O$ ), type A patients had significantly lower OS and DMFS (adjusted hazard ratio $(H R)=1.49,95 \% \mathrm{Cl} 1.03-2.17, P=0.036 ; \mathrm{HR}=1.68$, $95 \% \mathrm{Cl} 1.13-2.51, P=0.011$, respectively); similar results were obtained in CRT cohort. Subgroup analyses of the entire population showed that lower OS conferred by blood type A was not significantly modified by age, smoking status, drinking status, immunoglobulin A against Epstein-Barr virus viral capsid antigen (VCA-IgA) titre, or chemotherapy; however, lower OS was not observed in female patients or patients with early clinical stage disease.

Conclusion: ABO blood group is associated with survival in NPC; patients with blood type A had significantly lower OS and DMFS than patients with non-A blood types.

Nasopharyngeal carcinoma (NPC) is a non-lymphomatous, squamous-cell carcinoma that occurs in the epithelial lining of the nasopharynx. Despite improvements in more precise imaging, radiotherapy techniques (Lai et al, 2011; Peng et al, 2012) and chemotherapy (Baujat et al, 2006; Ouyang et al, 2013), the survival rates of patients with advanced NPC remain poor. Identification of novel prognostic factors to recognise patients at high risk is warranted. Recently, the associations between ABO blood group and survival have been evaluated in pancreatic cancer (Engin et al, 2012; Rahbari et al, 2012), locoregional renal cell carcinoma (Kaffenberger et al, 2012), triple-negative breast cancer (Yu et al,
2012) or breast cancer (Stamatakos et al, 2009; Gates et al, 2012), oesophageal squamous cell carcinoma (Nozoe et al, 2004), and laryngeal squamous cell carcinoma (Adam et al, 2012).

However, NPC has a distinct epidemiology, aetiology (Chang and Adami, 2006) and clinical manifestation (Wei and Sham, 2005) compared with other cancers, including other types of head and neck cancers. It remains unknown whether the $\mathrm{ABO}$ blood groups are associated with survival of NPC patients; therefore, we performed this study to elucidate the effect of $\mathrm{ABO}$ blood groups on the clinicopathologic features of NPC and to determine whether certain blood type is an independent predictor of prognosis.

\footnotetext{
*Correspondence: Professor F-Y Xie; E-mail: xiefy@sysucc.org.cn

${ }^{3}$ These authors contributed equally to this work.
}

Received 14 June 2013; revised 17 August 2013; accepted 19 August 2013; published online 10 September 2013 


\section{MATERIALS AND METHODS}

Patients. The study was reviewed and approved by the Human Ethics Approval Committee at Sun Yat-sen University Cancer Center. After reviewing medical records, the first cohort included 924 from 986 patients of WHO histological type III (Shanmugaratnam and Sobin, 1991) treated with intensitymodulated radiotherapy (IMRT) between January 2003 and December 2009, while the second cohort included 1193 from 1406 patients of WHO histological type III treated with conventional radiotherapy (CRT) between January 2005 and December 2006 (the inclusion criteria were presented in Supplementary Information). We collected data on basic characteristics including age, gender, cigarette smoking status at diagnosis, alcohol drinking status at diagnosis, pre-treatment titre of serum immunoglobulin A against Epstein-Barr virus viral capsid antigen (VCA-IgA), and ABO blood type. Patients with missing data were excluded from this study. All patients were restaged by the seventh edition of AJCC/UICC Staging System for NPC (Edge et al, 2010).

All patients were treated by IMRT or CRT with or without chemotherapy; the radiation techniques and chemotherapy regimens have been described previously (Ma et al, 2007; Liang et al, 2009; Chen et al, 2012). The follow-up duration was calculated from the first day of therapy to either the day of death or the day of last examination.

Statistical analysis. The following end points (interval to the first defining event) were estimated: overall survival (OS), locoregional relapse-free survival (LRFS), and distant metastasis-free survival (DMFS). All were examined using Kaplan-Meier methods and compared using log-rank test (Kaplan and Meier, 1958). Multivariate analyses were performed using Cox proportional hazards model (Cox, 1972). Two-sided $P$-values $<0.05$ were considered significant. All tests were conducted using SPSS 16.0 (SPSS Inc., Chicago, IL, USA).

\section{RESULTS}

Baseline characteristics. Basic characteristics of patients in each cohort are compared in terms of blood type A and non- $A(B, A B$, and $\mathrm{O}$; Supplementary Table 1). The proportions of blood types $\mathrm{O}$, $\mathrm{A}, \mathrm{B}$, and $\mathrm{AB}$ were approximately similar to those of the cases in the recent case-control study (Sheng et al, 2013): 41.1\%, 27.1\%, $24.9 \%$, and $6.9 \%$ in the IMRT cohort, and $39.8 \%, 27.1 \%, 26.7 \%$, and $6.4 \%$ in the CRT cohort, respectively. There were no differences in the distributions of basic characteristics between blood type A and non-A in both cohorts $(P \geqslant 0.067)$.

Within a median follow-up duration of 68.0 months (range, 2.0-123.8 months) for the entire population, $8.3 \%$ (175 out of 2117) patients developed locoregional relapse, $12.5 \%$ (265 out of 2117) developed distant metastases, and $17.6 \%$ (373 out of 2117) died. The 3- and 5-year survival rates for the entire population were as follows: OS, $90.7 \%$ and $83.9 \%$; LRFS, $94.2 \%$ and $91.3 \%$; DMFS, $89.6 \%$ and $87.1 \%$.

Effect of ABO blood groups on survival in the IMRT cohort. Compared with patients with blood type $\mathrm{O}$, the hazard ratios (HRs) in univariate analysis among patients with blood type A were 1.54 (95\% CI 1.01-2.35; $P=0.045)$ for OS, 1.10 (95\% CI $0.59-2.05$; $P=0.756$ ) for LRFS, and 1.38 (95\% CI $0.89-$ 2.14; $P=0.146)$ for DMFS. Significant differences in OS and

Table 1. Univariate and multivariate analyses of overall survival, locoregional relapse-free survival, and distant metastasis-free survival for the 924 patients with NPC in the intensity-modulated radiotherapy cohort

\begin{tabular}{|c|c|c|c|c|c|c|}
\hline \multirow[b]{2}{*}{ Survival } & \multicolumn{4}{|c|}{ Blood group } & \multicolumn{2}{|c|}{ Blood type A } \\
\hline & $O(n=380)$ & $A(n=250)$ & $B(n=230)$ & $\mathrm{AB}(n=64)$ & Non-A $(n=674)$ & $A(n=250)$ \\
\hline \multicolumn{7}{|c|}{ Overall survival } \\
\hline $\begin{array}{l}\text { No. of events } \\
\text { uHR }(95 \% \mathrm{Cl}) \\
P \\
\text { aHR }(95 \% \mathrm{Cl})^{\mathrm{a}} \\
P\end{array}$ & $\begin{array}{c}43 \\
1.00 \\
1.00\end{array}$ & $\begin{array}{c}43 \\
1.54(1.01-2.35) \\
0.045 \\
1.58(1.03-2.43) \\
0.035\end{array}$ & $\begin{array}{c}31 \\
1.18(0.74-1.87) \\
0.481 \\
1.19(0.75-1.90) \\
0.465\end{array}$ & $\begin{array}{c}8 \\
1.01(0.47-2.15) \\
0.981 \\
1.36(0.63-2.92) \\
0.432\end{array}$ & $\begin{array}{c}82 \\
1.00 \\
1.00\end{array}$ & $\begin{array}{c}43 \\
1.45(1.00-2.10) \\
0.048 \\
1.49(1.03-2.17) \\
0.036\end{array}$ \\
\hline \multicolumn{7}{|c|}{ Locoregional relapse-free survival } \\
\hline $\begin{array}{l}\text { No. of events } \\
\text { uHR }(95 \% \mathrm{Cl}) \\
P \\
\text { aHR }(95 \% \mathrm{Cl})^{\mathrm{a}} \\
P\end{array}$ & $\begin{array}{c}24 \\
1.00 \\
1.00\end{array}$ & $\begin{array}{c}17 \\
1.10(0.59-2.05) \\
0.756 \\
1.16(0.62-2.17) \\
0.638\end{array}$ & $\begin{array}{c}16 \\
1.13(0.60-2.12) \\
0.709 \\
1.14(0.60-2.14) \\
0.694\end{array}$ & $\begin{array}{c}4 \\
1.00(0.35-2.90) \\
00.994 \\
1.14(0.39-3.32) \\
0.806\end{array}$ & $\begin{array}{c}44 \\
1.00 \\
1.00\end{array}$ & $\begin{array}{c}17 \\
1.06(0.60-1.85) \\
0.845 \\
1.10(0.63-1.93) \\
0.746\end{array}$ \\
\hline \multicolumn{7}{|c|}{ Distant metastasis-free survival } \\
\hline $\begin{array}{l}\text { No. of events } \\
\text { uHR }(95 \% \mathrm{Cl}) \\
P \\
\text { aHR }(95 \% \mathrm{Cl})^{\mathrm{a}} \\
P\end{array}$ & $\begin{array}{c}43 \\
1.00 \\
1.00\end{array}$ & $\begin{array}{c}38 \\
1.38(0.89-2.14) \\
0.146 \\
1.62(1.04-2.52) \\
0.033\end{array}$ & $\begin{array}{c}22 \\
0.84(0.50-1.41) \\
0.511 \\
0.90(0.54-1.51) \\
0.685\end{array}$ & $\begin{array}{c}5 \\
0.65(0.26-1.65) \\
0.369 \\
0.93(0.37-2.37) \\
0.882\end{array}$ & $\begin{array}{c}70 \\
1.00 \\
1.00\end{array}$ & $\begin{array}{c}38 \\
1.52(1.02-2.25) \\
0.039 \\
1.68(1.13-2.51) \\
0.011\end{array}$ \\
\hline \multicolumn{7}{|c|}{$\begin{array}{l}\text { Abbreviations: aHR = adjusted hazard ratio; } \mathrm{Cl}=\text { confidence interval; } \mathrm{NPC}=\text { nasopharyngeal carcinoma; } \mathrm{uHR}=\text { unadjusted hazard ratio; VCA-lgA=immunoglobulin } \mathrm{A} \text { against Epstein-Barr virus } \\
\text { viral capsid antigen. } \\
\text { a Adjusted for age group }(\leqslant 30,31-40,41-50,51-60 \text {, and } \geqslant 61 \text { years-old), gender, smoking status at diagnosis (yes vs no), drinking status at diagnosis (yes vs no), T-stage (T1/T2/T3/T4), N-stage } \\
\text { (NO/N1/N2/N3), titre of VCA-lgA ( } \leqslant 1: 160 \text { vs }>1: 160) \text {, and type of chemotherapy. }\end{array}$} \\
\hline
\end{tabular}


DMFS between patients with blood type A and blood type $\mathrm{O}$ were observed in multivariate analyses; the adjusted HRs for OS, LRFS, and DMFS were 1.58 (95\% CI 1.03-2.43; $P=0.035), 1.16$ (95\% CI $0.62-2.17 ; P=0.638$ ), and 1.62 (95\% CI 1.04-2.52; $P=0.033$ ), respectively, after accounting for age $(\leqslant 30,31-40,41-50,51-60$, and $\geqslant 61$ years-old), gender, smoking status, drinking status, T-stage, N-stage, VCA-IgA titer and chemotherapy. However, no significant differences in OS, LRFS, or DMFS were observed for patients with blood type $\mathrm{B}$ or $\mathrm{AB}$ in univariate or multivariate analysis when compared with patients with blood type $\mathrm{O}$ (Table 1).

We next examined the effect of $\mathrm{ABO}$ blood groups in terms of type A and non-A types. Blood type A was not significantly associated with LRFS; however, patients with type A had a significant lower OS and DMFS than those with non-A types $(\mathrm{HR}=1.45,95 \%$ CI $1.00-2.10, P=0.048$ for OS; $\mathrm{HR}=1.52,95 \%$ CI $1.02-2.25, P=0.039$ for DMFS; respectively) in univariate analysis (Supplementary Figure 1; Table 1). In addition, the higher risks of death and distant metastasis for patients with type A vs non-A types remained significant in multivariate analyses $(\mathrm{HR}=1.49,95 \%$ CI $1.03-2.17, P=0.036$ for OS; $\mathrm{HR}=1.68,95 \%$ CI $1.13-2.51, P=0.011$ for DMFS, respectively); no significant differences in LRFS were observed (adjusted $\mathrm{HR}=1.10,95 \% \mathrm{CI}$ $0.63-1.93 ; P=0.746$; Table 1 ).

Effect of ABO blood groups on survival in the CRT cohort. In this cohort, compared with patients with blood type O, patients with type A had significant lower OS and DMFS with HR of 1.46 (95\% CI $1.07-1.98 ; P=0.017)$ and 1.73 (95\% CI 1.18-2.53; $P=0.005$ ), respectively, in univariate analysis (Table 2); similar trends were not observed in the IMRT cohort. Differences in OS and DMFS between patients with type $\mathrm{A}$ and type $\mathrm{O}$ remained significant in multivariate analyses (Table 2). In addition, the effect of $\mathrm{ABO}$ blood groups, in terms of blood type $\mathrm{A}$ and non-A types in the CRT cohort was similar to results of the IMRT cohort (Supplementary Figure 2; Table 2).

Subgroup analyses. The above results showed that the radiation technique barely affected the effect of blood group on survival in NPC. We therefore merged the IMRT and CRT cohort to further assess the association between $\mathrm{ABO}$ blood groups and $\mathrm{OS}$ in subgroups stratified by other prognoses. As shown in Table 3, the increased risk of death conferred by blood type A was not significantly modified by age (categorical), smoking status, drinking status, VCA-IgA titre, or type of chemotherapy. However, the increased risk of death conferred by blood type A was not observed among female patients (adjusted $\mathrm{HR}=1.18,95 \% \mathrm{CI}$ $0.70-1.98 ; P=0.531$ ), patients with early stage disease (adjusted $\mathrm{HR}=1.56,95 \%$ CI $0.85-2.85 ; P=0.150)$, or patients treated with radiotherapy alone (adjusted $\mathrm{HR}=0.74, \quad 95 \%$ CI $0.41-1.35$; $P=0.332)$.

\section{DISCUSSION}

Previous studies have evaluated the association of $\mathrm{ABO}$ blood groups with the aetiology of NPC (Turkoz et al, 2011; Sheng et al, 2013). However, no studies have examined its effect on survival of patients with established NPC. This is the first investigation to demonstrate that $\mathrm{ABO}$ blood groups are associated with patient survival in NPC, as patients with type A had independent, significantly lower OS and DMFS.

Our findings are quite similar to previous studies in pancreatic cancer (Engin et al, 2012; Rahbari et al, 2012), renal cell carcinoma (Kaffenberger et al, 2012), and breast cancer (Stamatakos et al,

Table 2. Univariate and multivariate analyses of overall survival, locoregional relapse-free survival, and distant metastasis-free survival in the 1193 patients with NPC in the conventional radiotherapy cohort

\begin{tabular}{|c|c|c|c|c|c|c|}
\hline \multirow[b]{2}{*}{ Survival } & \multicolumn{4}{|c|}{ Blood group } & \multicolumn{2}{|c|}{ Blood type A } \\
\hline & $O(n=475)$ & $A(n=323)$ & B $(n=318)$ & $A B(n=77)$ & Non-A $(n=870)$ & $A(n=323)$ \\
\hline \multicolumn{7}{|c|}{ Overall survival } \\
\hline $\begin{array}{l}\text { No. of events } \\
\text { uHR }(95 \% \mathrm{Cl}) \\
P \\
\text { aHR }(95 \% \mathrm{Cl})^{\mathbf{a}} \\
P\end{array}$ & $\begin{array}{c}85 \\
1.00 \\
1.00\end{array}$ & $\begin{array}{c}79 \\
1.46(1.07-1.98) \\
0.017 \\
1.75(1.24-2.47) \\
0.001\end{array}$ & $\begin{array}{c}70 \\
1.26(0.92-1.74) \\
0.146 \\
1.34(0.94-1.91) \\
0.110\end{array}$ & $\begin{array}{c}14 \\
1.02(0.58-1.79) \\
0.958 \\
1.07(0.58-1.99) \\
0.832\end{array}$ & $\begin{array}{l}169 \\
1.00 \\
1.00\end{array}$ & $\begin{array}{c}79 \\
1.33(1.02-1.73) \\
0.038 \\
1.54(1.15-2.07) \\
0.004\end{array}$ \\
\hline \multicolumn{7}{|c|}{ Locoregional relapse-free survival } \\
\hline $\begin{array}{l}\text { No. of events } \\
\text { uHR }(95 \% \mathrm{Cl}) \\
P \\
\text { aHR }(95 \% \mathrm{Cl})^{\mathrm{a}} \\
P\end{array}$ & $\begin{array}{c}53 \\
1.00 \\
1.00\end{array}$ & $\begin{array}{c}28 \\
0.81(0.51-1.29) \\
0.376 \\
0.96(0.56-1.64) \\
0.876\end{array}$ & $\begin{array}{c}23 \\
0.66(0.40-1.07) \\
0.093 \\
0.76(0.44-1.33) \\
0.340\end{array}$ & $\begin{array}{c}10 \\
1.18(0.60-2.32) \\
0.635 \\
1.43(0.69-2.97) \\
0.338\end{array}$ & $\begin{array}{c}86 \\
1.00 \\
1.00\end{array}$ & $\begin{array}{c}28 \\
0.91(0.60-1.40) \\
0.672 \\
1.01(0.61-1.65) \\
0.978\end{array}$ \\
\hline \multicolumn{7}{|c|}{ Distant metastasis-free survival } \\
\hline $\begin{array}{l}\text { No. of events } \\
\text { uHR }(95 \% \mathrm{Cl}) \\
P \\
\text { aHR }(95 \% \mathrm{Cl})^{\text {a }} \\
P\end{array}$ & $\begin{array}{c}50 \\
1.00 \\
1.00\end{array}$ & $\begin{array}{c}56 \\
1.73(1.18-2.53) \\
0.005 \\
1.77(1.18-2.67) \\
0.006\end{array}$ & $\begin{array}{c}43 \\
1.32(0.88-1.98) \\
0.188 \\
1.24(0.80-1.92) \\
0.332\end{array}$ & $\begin{array}{c}9 \\
1.10(0.54-2.24) \\
0.790 \\
1.15(0.56-2.35) \\
0.712\end{array}$ & $\begin{array}{l}102 \\
1.00 \\
1.00\end{array}$ & $\begin{array}{c}56 \\
1.54(1.11-2.14) \\
0.009 \\
1.61(1.13-2.28) \\
0.008\end{array}$ \\
\hline \multicolumn{7}{|c|}{$\begin{array}{l}\text { Abbreviations: aHR= adjusted hazard ratio; } \mathrm{Cl}=\text { confidence interval; } \mathrm{NPC}=\text { nasopharyngeal carcinoma; uHR = unadjusted hazard ratio; VCA-lgA = immunoglobulin } \mathrm{A} \text { against Epstein-Barr virus } \\
\text { viral capsid antigen. } \\
\text { a Adjusted for age group ( } \leqslant 30,31-40,41-50,51-60 \text {, and } \geqslant 61 \text { years-old), gender, smoking status at diagnosis (yes vs no), drinking status at diagnosis (yes vs no), T-stage (T1/T2/T3/T4), N-stage } \\
\text { (N0/N1/N2/N3), titre of VCA-lgA ( } \leqslant 1: 160 \text { vs }>1: 160) \text {, and type of chemotherapy. }\end{array}$} \\
\hline
\end{tabular}


Table 3. Subgroup analysis of OS by patient characteristics for the entire population of patients with NPC $(n=2117)$

No. of events/no. at risk

\begin{tabular}{|c|c|c|c|c|c|c|}
\hline Characteristic & $\begin{array}{l}\text { 5-Year OS } \\
\text { rate (\%) }\end{array}$ & $\begin{array}{c}P \text { by each } \\
\text { characteristic }\end{array}$ & $\begin{array}{l}\text { Non-A blood } \\
\text { types }\end{array}$ & $\begin{array}{l}\text { Blood } \\
\text { type A }\end{array}$ & $\begin{array}{c}\text { Adjusted HR } \\
(95 \% \mathrm{Cl})^{\mathrm{a}}\end{array}$ & $\begin{array}{l}P \text { between blood } \\
\text { type } A \text { and non-A types }\end{array}$ \\
\hline Overall & 83.9 & & $247 / 1540$ & $126 / 577$ & $1.44(1.16-1.78)$ & 0.001 \\
\hline Age & & $<0.001$ & & & & \\
\hline $\begin{array}{l}\leqslant 45 \text { years-old } \\
>45 \text { years-old }\end{array}$ & $\begin{array}{l}89.4 \\
78.3\end{array}$ & & $\begin{array}{l}79 / 758 \\
168 / 782\end{array}$ & $\begin{array}{l}50 / 308 \\
76 / 269\end{array}$ & $\begin{array}{l}1.65(1.16-2.36) \\
1.37(1.04-1.80)\end{array}$ & $\begin{array}{l}0.006 \\
0.024\end{array}$ \\
\hline Gender & & 0.002 & & & & \\
\hline $\begin{array}{l}\text { Male } \\
\text { Female }\end{array}$ & $\begin{array}{l}82.5 \\
88.2\end{array}$ & & $\begin{array}{c}200 / 1171 \\
47 / 369\end{array}$ & $\begin{array}{l}102 / 423 \\
24 / 154\end{array}$ & $\begin{array}{l}1.48(1.16-1.88) \\
1.18(0.70-1.98)\end{array}$ & $\begin{array}{l}0.001 \\
0.531\end{array}$ \\
\hline Smoking status & & $<0.001$ & & & & \\
\hline $\begin{array}{l}\text { Yes } \\
\text { No }\end{array}$ & $\begin{array}{l}79.3 \\
87.8\end{array}$ & & $\begin{array}{l}148 / 703 \\
99 / 837\end{array}$ & $\begin{array}{l}73 / 261 \\
53 / 316\end{array}$ & $\begin{array}{l}1.36(1.02-1.80) \\
1.55(1.11-2.16)\end{array}$ & $\begin{array}{l}0.036 \\
0.011\end{array}$ \\
\hline Drinking status & & $<0.001$ & & & & \\
\hline $\begin{array}{l}\text { Yes } \\
\text { No }\end{array}$ & $\begin{array}{l}76.5 \\
85.1\end{array}$ & & $\begin{array}{c}40 / 204 \\
207 / 1336\end{array}$ & $\begin{array}{c}35 / 90 \\
91 / 487\end{array}$ & $\begin{array}{l}2.18(1.37-3.47) \\
1.33(1.01-1.76)\end{array}$ & $\begin{array}{l}0.001 \\
0.042\end{array}$ \\
\hline VCA-IgA & & 0.038 & & & & \\
\hline $\begin{array}{l}\leqslant 1: 160 \\
>1: 160\end{array}$ & $\begin{array}{l}85.7 \\
81.9\end{array}$ & & $\begin{array}{l}114 / 797 \\
133 / 743\end{array}$ & $\begin{array}{l}60 / 305 \\
66 / 272\end{array}$ & $\begin{array}{l}1.47(1.07-2.02) \\
1.38(1.03-1.86)\end{array}$ & $\begin{array}{l}0.017 \\
0.033\end{array}$ \\
\hline Clinical stage & & $<0.001$ & & & & \\
\hline $\begin{array}{l}I+I I \\
I I I+I V\end{array}$ & $\begin{array}{l}93.4 \\
79.7\end{array}$ & & $\begin{array}{c}33 / 447 \\
214 / 1093\end{array}$ & $\begin{array}{c}16 / 185 \\
110 / 392\end{array}$ & $\begin{array}{l}1.56(0.85-2.85) \\
1.50(1.19-1.89)\end{array}$ & $\begin{array}{l}0.150 \\
0.001\end{array}$ \\
\hline Chemotherapy $^{b}$ & & $<0.001$ & & & & \\
\hline $\begin{array}{l}\text { None } \\
\text { IC } \\
\text { CC } \\
\text { IC }+ \text { CC }\end{array}$ & $\begin{array}{l}89.1 \\
70.6 \\
84.2 \\
85.5\end{array}$ & & $\begin{array}{l}49 / 346 \\
53 / 191 \\
85 / 561 \\
45 / 342\end{array}$ & $\begin{array}{c}15 / 130 \\
29 / 64 \\
47 / 232 \\
29 / 126\end{array}$ & $\begin{array}{l}0.74(0.41-1.35) \\
1.60(1.01-2.53) \\
1.60(1.11-2.30) \\
1.64(1.02-2.66)\end{array}$ & $\begin{array}{l}0.332 \\
0.045 \\
0.011 \\
0.043\end{array}$ \\
\hline
\end{tabular}

Abbreviations: $C C=$ concomitant chemotherapy; $\mathrm{Cl}=$ confidence interval; $\mathrm{HR}=$ hazard ratio; $\mathrm{IC}=$ induction chemotherapy; $\mathrm{NPC}=$ nasopharyngeal carcinoma; $\mathrm{OS}=$ overall survival; VCA-IgA = immunoglobulin A against Epstein-Barr virus viral capsid antigen.

${ }^{a}$ Adjusted for age group ( $\leqslant 30,31-40,41-50,51-60$, and $\geqslant 61$ years-old), gender, smoking status at diagnosis (yes vs no), drinking status at diagnosis (yes vs no), $T$-stage ( $\left.11 / T 2 / T 3 / T 4\right)$, $\mathrm{N}$-stage (N0/N1/N2/N3), titre of VCA-lgA ( $\leqslant 1: 160 \mathrm{vs}>1: 160)$, radiation technique, and type of chemotherapy.

${ }^{\mathbf{b}}$ The subgroup of concomitant and adjuvant chemotherapy was excluded from analysis because of particular small number of patients $(n=126)$.

2009). As the first report, there are few existing comparable studies in NPC, or even other types of head and neck cancer. A study (Adam et al, 2012) indicated no association between blood type and 5-year survival and mortality in laryngeal cancer, but these results are inconclusive as only 143 patients were included.

In the subgroup analyses, we found that the increased risks associated with blood type A were restricted to male patients. However, this was not unexpected. A case-control study in NPC (Sheng et al, 2013) observed a significantly higher rate of distant metastasis among male patients, but not female patients, with blood type A compared with non-A types $(6.8 \%$ vs $3.5 \%$; $P=0.027$ ), which directly support the poorer prognostic value of blood type $\mathrm{A}$ in males. In addition, blood type A was associated with more advanced NPC in male patients, but not in female patients (Sheng et al, 2013); this suggests a lower survival rate in male patients with blood type A, despite the fact that no such association was observed in our study. Additionally, the recent study (Lu et al, 2013) indicated that the female sex was positively associated with an early $\mathrm{T}$-stage, $\mathrm{N}$-stage, and clinical stage; reduced disease progression and cancer-related deaths, and was a favourable independent prognostic factor. In our study, female patients with blood type A had a higher proportion of early stage disease than those with non-A types had $(38.6 \%$ vs $29.5 \%$; $P=0.043$ ). Therefore, the protective prognosis of female sex may confound the negative effects of blood type A on predicting survival of NPC, as we detected interactions $(P=0.007)$ between gender and blood type (A/non-A). Second, blood type A was not associated with survival in patients with stage I and II disease. This may be explained by the fact that patients with early stage disease had relatively high rates of survival in general; therefore, it was difficult to observe significant survival differences according to a certain prognostic factor. Finally, as patients treated with RT alone mostly had early stage disease, it seems reasonable that no effects of blood group were observed in these patients. More importantly, small number of patients and low event rates in the female stratum, early stage stratum, and RT alone stratum are significant factors that cannot be ignored.

It is still not clear why $\mathrm{ABO}$ blood groups affect the survival of patients with NPC. As no significant differences in the basic characteristics of patients with blood type A and non-A types were observed, it is difficult to explain the effect of $\mathrm{ABO}$ blood groups based on this point. Underlying molecular and pathogenic differences may have more important roles in the effect of $\mathrm{ABO}$ blood groups on survival (see Supplementary materials).

In conclusion, this study provides the first evidence of association between $\mathrm{ABO}$ blood groups and survival in patients with NPC; patients with blood type A had poorer OS and DMFS than those with non-A types. Further basic researches into tumour genetic or biological differences associated with the $\mathrm{ABO}$ blood groups are required. 


\section{ACKNOWLEDGEMENTS}

This work was supported by grants from the National Natural Science Foundation of China (no. 30930045) and the Science Foundation of Key Hospital Clinical Program of Ministry of Health PR China (no. 2010-439).

\section{CONFLICT OF INTEREST}

The authors declare no conflict of interest.

\section{REFERENCES}

Adam SI, Wilson KM, Overholser SM, Khabbaz E, Moreno K, Patil YJ (2012) Are laryngeal squamous cell carcinoma incidence and patient mortality a function of $\mathrm{ABO}$ blood grouping? A retrospective study. J Laryngol Otol 126(2): 180-184.

Baujat B, Audry H, Bourhis J, Chan AT, Onat H, Chua DT, Kwong DL, Al-Sarraf M, Chi KH, Hareyama M, Leung SF, Thephamongkhol K, Pignon JP (2006) Chemotherapy in locally advanced nasopharyngeal carcinoma: an individual patient data meta-analysis of eight randomized trials and 1753 patients. Int J Radiat Oncol Biol Phys 64(1): 47-56.

Chang ET, Adami HO (2006) The enigmatic epidemiology of nasopharyngeal carcinoma. Cancer Epidemiol Biomarkers Prev 15(10): 1765-1777.

Chen L, Mao Y-P, Xie F-Y, Liu L-Z, Sun Y, Tian L, Tang L-L, Lin A-H, Li L, Ma J (2012) The seventh edition of the UICC/AJCC staging system for nasopharyngeal carcinoma is prognostically useful for patients treated with intensity-modulated radiotherapy from an endemic area in China. Radiother Oncol 104(3): 331-337.

Cox DR (1972) Regression models and life tables. J R Stat Soc B 34: 187-220.

Edge SB, Byrd DR, Compton CC, Fritz AG, Greene FL, Trotti A (2010) AJCC Cancer Staging Handbook from the AJCC Cancer Staging Manual. 7th edn. Springer: New York, NY, USA.

Engin H, Bilir C, Ustun H, Gokmen A (2012) ABO blood group and risk of pancreatic cancer in a Turkish population in Western Blacksea region. Asian Pac J Cancer Prev 13(1): 131-133.

Gates MA, Xu M, Chen WY, Kraft P, Hankinson SE, Wolpin BM (2012) ABO blood group and breast cancer incidence and survival. Int J Cancer 130(9): 2129-2137.

Kaffenberger SD, Morgan TM, Stratton KL, Boachie AM, Barocas DA, Chang SS, Cookson MS, Herrell SD, Smith JA, Clark PE (2012) ABO blood group is a predictor of survival in patients undergoing surgery for renal cell carcinoma. BJU Int 110(11b): E641-E646.

Kaplan EL, Meier P (1958) Nonparametric estimation from incomplete observation. J Am Stat Assoc 53: 457-481.

Lai SZ, Li WF, Chen L, Luo W, Chen YY, Liu LZ, Sun Y, Lin AH, Liu MZ, Ma J (2011) How does intensity-modulated radiotherapy versus conventional two-dimensional radiotherapy influence the treatment results in nasopharyngeal carcinoma patients? Int J Radiat Oncol Biol Phys 80(3): 661-668.
Liang SB, Sun Y, Liu LZ, Chen Y, Chen L, Mao YP, Tang LL, Tian L, Lin AH, Liu MZ, Li L, Ma J (2009) Extension of local disease in nasopharyngeal carcinoma detected by magnetic resonance imaging: improvement of clinical target volume delineation. Int J Radiat Oncol Biol Phys 75(3): $742-750$.

Lu X, Wang FL, Guo X, Wang L, Zhang HB, Xia WX, Li SW, Li NW, Qian CN, Xiang YQ (2013) Favorable prognosis of female patients with nasopharyngeal carcinoma. Chin J Cancer 32(5): 283-288.

Ma J, Liu L, Tang L, Zong J, Lin A, Lu T, Cui N, Cui C, Li L (2007) Retropharyngeal lymph node metastasis in nasopharyngeal carcinoma: prognostic value and staging categories. Clin Cancer Res 13(5): $1445-1452$.

Nozoe T, Ezaki T, Baba H, Kakeji Y, Maehara Y (2004) Correlation of $\mathrm{ABO}$ blood group with clinicopathologic characteristics of patients with esophageal squamous cell carcinoma. Dis Esophagus 17(2): 146-149.

Ouyang PY, Xie C, Mao YP, Zhang Y, Liang XX, Su Z, Liu Q, Xie FY (2013) Significant efficacies of neoadjuvant and adjuvant chemotherapy for nasopharyngeal carcinoma by meta-analysis of published literature-based randomized, controlled trials. Ann Oncol 24(8): 2136-2146.

Peng G, Wang T, Yang KY, Zhang S, Zhang T, Li Q, Han J, Wu G (2012) A prospective, randomized study comparing outcomes and toxicities of intensity-modulated radiotherapy $v s$ conventional two-dimensional radiotherapy for the treatment of nasopharyngeal carcinoma. Radiother Oncol 104(3): 286-293.

Rahbari NN, Bork U, Hinz U, Leo A, Kirchberg J, Koch M, Buchler MW, Weitz J (2012) AB0 blood group and prognosis in patients with pancreatic cancer. BMC Cancer 12: 319.

Shanmugaratnam K, Sobin LH (1991) Histological typing of tumors of upper respiratory tract and ear. In International histological classification of tumours, Shanmugaratnam K, Sobin LH (eds), 2nd edn, pp 32-33. Geneva: WHO.

Sheng L, Sun X, Zhang L, Su D (2013) ABO blood group and nasopharyngeal carcinoma risk in a population of Southeast China. Int J Cancer 133(4): 893-897.

Stamatakos M, Kontzoglou K, Safioleas P, Safioleas C, Manti C, Safioleas M (2009) Breast cancer incidence in Greek women in relation to ABO blood groups and Rh factor. Int Semin Surg Oncol 6: 14.

Turkoz FP, Celenkoglu G, Dogu GG, Kalender ME, Coskun U, Alkis N, Ozkan M, Turk HM, Arslan UY (2011) Risk factors of nasopharyngeal carcinoma in Turkey-an epidemiological survey of the Anatolian Society of Medical Oncology. Asian Pac J Cancer Prev 12(11): 3017-3021.

Wei WI, Sham JS (2005) Nasopharyngeal carcinoma. Lancet 365(9476): 2041-2054.

Yu J, Gao F, Klimberg VS, Margenthaler JA (2012) ABO blood type/Rh factor and the incidence and outcomes for patients with triple-negative breast cancer. Ann Surg Oncol 19(10): 3159-3164.

This work is published under the standard license to publish agreement. After 12 months the work will become freely available and the license terms will switch to a Creative Commons AttributionNonCommercial-Share Alike 3.0 Unported License.

Supplementary Information accompanies this paper on British Journal of Cancer website (http://www.nature.com/bjc) 